Hepatitis B and D Protocols

Volume 1 


\section{METHODS IN MOLECULAR MEDICINETM}

\section{John M. Walker, SERIES EDITOR}

99. Pain Research: Methods and Protocols, edited by David Z. Luo, 2004

98. Tumor Necrosis Factor: Methods and Protocols, edited by Angelo Corti and Pietro Ghezzi, 2004

97. Molecular Diagnosis of Cancer: Methods and Protocols, Second Edition, edited by Joseph E. Roulston and John M. S. Bartlett, 2004

96. Hepatitis B and D Protocols: Volume 2, Immunology, Model Systems, and Clinical Studies, edited by Robert K. Hamatake and Johnson Y. N. Lau, 2004

95. Hepatitis B and D Protocols: Volume 1, Detection, Genotypes, and Characterization, edited by Robert K. Hamatake and Johnson Y. N. Lau, 2004

94. Molecular Diagnosis of Infectious Diseases, Second Edition, edited by Jochen Decker and Udo Reischl, 2004

93. Anticoagulants, Antiplatelets, and Thrombolytics, edited by Shaker A. Mousa, 2004

92. Molecular Diagnosis of Genetic Diseases, Second Edition, edited by Rob Elles and Roger Mountford, 2004

91. Pediatric Hematology: Methods and Protocols, edited by Nicholas J. Goulden and Colin G. Steward, 2003

90. Suicide Gene Therapy: Methods and Reviews, edited by Caroline J. Springer, 2004

89. The Blood-Brain Barrier: Biology and Research Protocols, edited by Sukriti Nag, 2003

88. Cancer Cell Culture: Methods and Protocols, edited by Simon P. Langdon, 2003

87. Vaccine Protocols, Second Edition, edited by Andrew Robinson, Michael J. Hudson, and Martin P. Cranage, 2003

86. Renal Disease: Techniques and Protocols, edited by Michael S. Goligorsky, 2003

85. Novel Anticancer Drug Protocols, edited by John K. Buolamwini and Alex A. Adjei, 2003
84. Opioid Research: Methods and Protocols, edited by Zhizhong Z. Pan, 2003

83. Diabetes Mellitus: Methods and Protocols, edited by Sabire Özcan, 2003

82. Hemoglobin Disorders: Molecular Methods and Protocols, edited by Ronald $L$. Nagel, 2003

81. Prostate Cancer Methods and Protocols, edited by Pamela J. Russell, Paul Jackson, and Elizabeth A. Kingsley, 2003

80. Bone Research Protocols, edited by Miep H. Helfrich and Stuart H. Ralston, 2003

79. Drugs of Abuse: Neurological Reviews and Protocols, edited by John Q. Wang, 2003

78. Wound Healing: Methods and Protocols, edited by Luisa A. DiPietro and Aime L. Burns, 2003

77. Psychiatric Genetics: Methods and Reviews, edited by Marion Leboyer and Frank Bellivier, 2003

76. Viral Vectors for Gene Therapy: Methods and Protocols, edited by Curtis A. Machida, 2003

75. Lung Cancer: Volume 2, Diagnostic and Therapeutic Methods and Reviews, edited by Barbara Driscoll, 2003

74. Lung Cancer: Volume 1, Molecular Pathology Methods and Reviews, edited by Barbara Driscoll, 2003

73. E. coli: Shiga Toxin Methods and Protocols, edited by Dana Philpott and Frank Ebel, 2003

72. Malaria Methods and Protocols, edited by Denise L. Doolan, 2002

71. Haemophilus influenzae Protocols, edited by Mark A. Herbert, Derek Hood, and E. Richard Moxon, 2002

70. Cystic Fibrosis Methods and Protocols, edited by William R. Skach, 2002

69. Gene Therapy Protocols, Second Edition, edited by Jeffrey R. Morgan, 2002

68. Molecular Analysis of Cancer, edited by Jacqueline Boultwood and Carrie Fidler, 2002 


\title{
Hepatitis B and D Protocols
}

Volume 1: Detection, Genotypes, and Characterization

\author{
Edited by \\ Robert K. Hamatake, PhD \\ Johnson Y. N. Lau, MD \\ Ribapharm Inc., Costa Mesa, CA
}

Forewords by

Timothy M. Block, PhD and Baruch S. Blumberg, MD, PhD

T. Jake Liang, MD 
(C) 2004 Humana Press Inc.

999 Riverview Drive, Suite 208

Totowa, New Jersey 07512

\section{www.humanapress.com}

All rights reserved. No part of this book may be reproduced, stored in a retrieval system, or transmitted in any form or by any means, electronic, mechanical, photocopying, microfilming, recording, or otherwise without written permission from the Publisher. Methods in Molecular Medicine ${ }^{\mathrm{TM}}$ is a trademark of The Humana Press Inc.

All authored papers, comments, opinions, conclusions, or recommendations are those of the author(s), and do not necessarily reflect the views of the publisher.

This publication is printed on acid-free paper. $\infty$

ANSI Z39.48-1984 (American Standards Institute) Permanence of Paper for Printed Library Materials.

Cover design by Patricia F. Cleary.

Cover illustration: HBV genome. Artwork supplied by Robert Hamatake, PhD. Background: Figure 1, Chapter 13, K. Abid and F. Negro.

\section{Photocopy Authorization Policy:}

Authorization to photocopy items for internal or personal use, or the internal or personal use of specific clients, is granted by Humana Press Inc., provided that the base fee of US \$25.00 per copy is paid directly to the Copyright Clearance Center at 222 Rosewood Drive, Danvers, MA 01923. For those organizations that have been granted a photocopy license from the CCC, a separate system of payment has been arranged and is acceptable to Humana Press Inc. The fee code for users of the Transactional Reporting Service is: [1-58829$105-7 / 04 \$ 25.00]$.

Printed in the United States of America. $\begin{array}{llllllllll}10 & 9 & 8 & 7 & 6 & 5 & 4 & 3 & 2 & 1\end{array}$

ISSN 1543-1894

Library of Congress Cataloging in Publication Data

Hepatitis B and D protocols / edited by Robert K. Hamatake, Johnson Y. N. Lau

p. ; cm. - (methods in molecular medicine; 95-96)

Includes bibliographical references and indexes.

Contents: v. 1. Detection, genotypes, and characterization-v. 2. Immunology, model systems, and clinical studies.

ISBN 1-58829-105-7 (v. 1 : alk. paper) E-ISBN 1-59259-669-X (v. 1) - ISBN 1-58829-108-1

(v. 2 : alk. paper) E-ISBN 1-59259-670-3 (v. 2)

1. Hepatitis B-Laboratory manuals. 2. Hepatitis B virus-Laboratory manuals. 3. Delta -associated agent-Laboratory manuals. 4. Delta infection-Laboratory manuals. I. Hamatake, Robert Kiyoshi, 1953- . II. Lau, Johnson Y. N. (Johnson Yiu-Nam). III. Series

[DNLM: 1. Hepatitis B. 2. Hepatitis D. WC 536 H53335 2004]

QR201.H46H43 2004

$616.3^{\prime} 623-1-\mathrm{dc} 21$

2003011624 
To our wives, April T.G. Hamatake and Jane W.S. Fang-Lau, for their unfailing support, and our children, Kyle Hamatake, David Hamatake, Grace (Ling-Ling) Lau, Gillian (Gi-Gi) Lau, and Gabrielle (Ching-Ching) Lau, for keeping us rejuvenated. 


\section{Foreword}

Despite the availability of an effective vaccine, there are still 400 million people, worldwide who are chronically infected with hepatitis B virus (HBV). For them, the vaccine, as currently applied, has no value. Given the possible consequences of HBV infection, the number of those chronically infected with HBV presents an enormous public health challenge. For example, the major etiology of hepatocellular carcinoma (HCC) is chronic infection with HBV. Although fifth in cancer incidence, worldwide, $\mathrm{HCC} /$ liver cancer is the third leading cause of cancer death. The high mortality associated with HCC arises because the disease is often detected late and is unresponsive to treatment. The number of deaths caused by PHCC is expected to rise over the next 20 years. Those chronically infected with HBV have a life risk of death to HCC of between 10 and 25\%. Even the limited efficacy of drugs for the treatment of chronic HBV helps underscore the point that this disease is responsive to therapy. Drugs that target the polymerase (e.g., hepsera and lamivudine) and interferon alpha represent two distinct strategies and show that both conventional antiviral and immunotherapeutic approaches can be used in management. However, the current inventory of therapeutics is inadequate. Interferon alpha is of limited value, only parenterally available, and fraught with adverse reactions. The polymerase inhibitors are undermined by either a high frequency of resistance or, in the case of hepsera, additional concerns about toxicity. Other areas of concern also remain. There is still no reliable means of predicting disease outcome for chronic carriers, making early detection of liver disease and decisions about drug efficacy, as well as who should be treated and for how long, difficult. Moreover, tests for HBV DNA levels (and other markers) are often of dubious quantitative value. Because HBV patients are becoming more sophisticated and more demanding about these markers and many follow their viremia (DNA) levels like investors follow the Dow Jones Industrial values, it is essential that meaningful lab values be provided. The current vaccines are effective, but they are expensive, and escape mutants may be a problem waiting to happen.

Thus, without a doubt, more work needs to be done in all of the key areas of the management of HBV.

The good news is that there have been important advances. A clearer picture about the kinds of drugs that can be effective, their pathogenesis, and the development of research tools should facilitate the discovery process.

It is the matter of research tools that these volumes address. In an almost encyclopedic fashion, Hamatake and Lau have assembled a comprehensive, "how to" guide for the study of HBV. It is worth noting that many of the methods described will have value in the study of other viruses and liver diseases in general, despite being highly focused upon HBV.

This is a very practical resource, in every respect. In more than 40 chapters, leaders in the field who have "been there" have contributed step-by-step "programmed" approaches, 
telling the readers how to reproduce their findings. It is something of a users guide for do-it-yourselfers.

It is not an overstatement to write that nearly every aspect of HBV research is covered, section by section, virus detection through vaccine and drug development. Thus, Hepatitis B and D Protocols is likely to become as essential a resource to those studying HBV as was the fabled Maniatis series (published by Cold Spring Harbor Press) for Molecular Biology. It is certainly going to get a great deal of attention in the Hepatitis B Foundation labs, and, because of its value, we hope it is used in labs throughout the world. The more it is used, the more likely HBV research will be advanced.

Timothy M. Block, PhD Professor and Director of the Jefferson Center and Hepatitis B Foundation Laboratory Thomas Jefferson University and President, Hepatitis B Foundation Doylestown, PA

Baruch S. Blumberg, MD, PhD Nobel Laureate, 1976

Senior Adviser to the President of Fox Chase Cancer Center and Professor of Medicine and Anthropology

University of Pennsylvania Philadelphia, PA 


\section{Foreword}

The identification of the "Australian antigen" by Dr. Blumberg, which was subsequently recognized to be the hepatitis B virus surface antigen, marks the discovery of an important pathogen for liver diseases. The virus was the first hepatitis virus discovered almost four decades ago. Despite the magnitude of the infection and the significant efforts by the scientific community, hepatitis B continues to be a global health problem affecting more than 350 million people worldwide. Many scientific milestones in basic and clinical research on hepatitis B had profound impact on this viral infection in the history of medicine: hepatitis B virus vaccine was introduced two decades ago; interferon alpha was approved for the treatment of chronic hepatitis B and two other antiviral drugs have also been approved; liver transplantation under high dose hepatitis B immunoglobulin coverage can now be offered to patients with end-stage hepatitis B related liver disease. These advances have also introduced new paradigms in our understanding of the fundamental concepts of viral infection in general. Certainly, more work looms ahead of us in order to ultimately conquer this viral infection. To equip the basic and clinical investigators with all the available tools is of utmost importance in this quest. As illustrated in this book, the marriage between basic science and clinical medicine is critical.

In the last few decades, we have witnessed the groundbreaking progress and the introduction of new clinical paradigms in hepatitis B virus infection. The next decade must underscore further application of our knowledge to translational research, bridging basic science and clinical medicine, and to capitalize on our understandings to conquer this viral infection. Undoubtedly, with all the scientific efforts contributed by many dedicated scientists and with our willingness to share knowledge, the common goal of improving human health by eradicating this virus can be achieved in this millennium.

T. Jake Liang, MD

Chief, Liver Diseases Section NIDDK National Institutes of Health

Bethesda, MD 


\section{Preface}

The 36 years since the identification of hepatitis B virus (HBV) in 1967 has seen the establishment of HBV virology as a rich and extensive field of science and the recognition of $\mathrm{HBV}$ as one of the top 10 leading causes of death in the world. There are an estimated 400 million people chronically infected with HBV worldwide with $20-30 \%$ of these projected to die from complications of chronic liver disease, including cirrhosis and liver cancer. Hepatitis delta virus (HDV) was first identified in 1980 as a novel transmissible agent distinct from HBV that requires the HBV envelope protein for its infectivity. HDV co-infection in chronic HBV patients is associated with a more severe disease outcome than those not co-infected. HBV and HDV infections represent a significant health burden to the worldwide community.

Despite the lack of an inflectable cell culture system, an enormous amount of information has been obtained on the virology and immunology of HBV and HDV infections. Modern molecular biological techniques and research with related viruses have enabled much of the HBV and HDV life cycle to be elucidated, leading to a number of therapeutic approaches for treating chronically infected patients. Innovative detection methods based on these findings and techniques have led to diagnostic and clinical monitoring assays of increasing sensitivity. However, our understanding of the viral life cycle and virus-host interactions is incomplete and will require much more research for a complete comprehension of the pathogenesis of disease caused by viral infection. Hepatitis B and D Protocols contains a collection of research techniques, divided into two volumes, used in the study of HBV and HDV. The authors represent a number of scientific disciplines, but share in common their interest in hepatitis research and their expertise in their respective areas. Although most of these techniques have been described in peerreviewed journals, these chapters provide far more detail and are written so that investigators can use them as manuals. A few reviews are included in some specialized areas such as antiviral testing and the design of clinical trials. We hope that this compilation of techniques used in the different areas of HBV and HDV research will prove useful to scientists and encourage multidisciplinary approaches to their research, so that clinical investigators will find it beneficial for their understanding of the current HBV and HDV research.

We would like to take this opportunity to extend our gratitude to our teachers and friends: Dr. Zhi Hong, Dr. Maria Seifer, Dr. David Standring, Professor P. C. Wu, Professor C. L. Lai, Dr. H. J. Lin, Professor Roger Williams, and Dr. Graeme J. M. Alexander. Without their guidance and support, we would not have the opportunity of presenting this highly practical manual to you today.

Robert K. Hamatake, PhD Johnson Yiu-Nam Lau, MD 


\section{Contents}

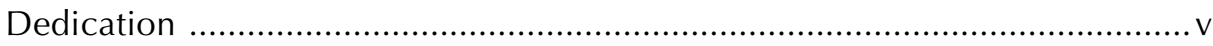

Foreword by Timothy M. Block and Baruch S. Blumberg ............................. vii

Foreword by T. Jake Liang ....................................................................... ix

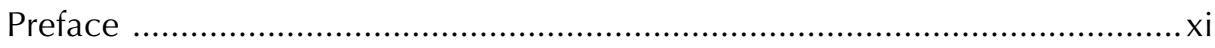

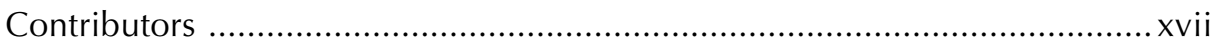

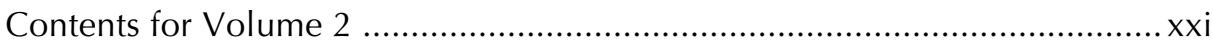

\section{Part I. Detection of Viral Markers}

1 Overview of Commercial HBV Assay Systems

Stefan Zeuzem

2 Detection of HBV DNA in Serum Using a PCR-Based Assay

Hau Tim Chung .

3 Detection of HBV DNA by Oligonucleotide Probing

Hsiang Ju Lin

4 Detection of HBV RNA in Serum of Patients

Wei Zhang, Hans Jörg Hacker, Maria Mildenberger, Qin Su, and Claus $\boldsymbol{H}$. Schröder.

5 Quantification of HBV Covalently Closed Circular DNA from Liver Tissue by Real-Time PCR

Scott Bowden, Kathy Jackson, Margaret Littlejohn, and Stephen Locarnini...

6 In Situ Hybridization for the Detection and Localization of HBV DNA in Liver Sections

Vicky C. H. Lai and Johnson Y. N. Lau

7 Quantitative Assay of Hepatitis B Surface Antigen in Serum or Plasma Using Laurell Electrophoresis

Wolfram H. Gerlich, Ulrike Wend, and Dieter Glebe

8 In Situ Detection of Hepatitis B Viral Antigens: An Immunohistochemical Approach

Jane W. S. Fang and Johnson Y. N. Lau

9 Detection of Hepatitis B Virus X Antigen by Immunohistochemistry and Western Blotting

Jie Liu and Mark A. Feitelson 
10 Detection of Serum HDV RNA by RT-PCR

Antonina Smedile, Maria Grazia Niro, and Mario Rizzetto............ 85

11 Nonradioisotopic In Situ Hybridization for HDV RNA

Francesco Negro

12 Detection and Characterization of Small and Large HDV Antigens

Thomas B. Macnaughton and Michael M. C. Lai.

13 Immunohistochemical Detection of Hepatitis Delta Antigen

Karim Abid and Francesco Negro

\section{Part II. Viral Genotypes and Variants}

14 HBV Vaccine-Escape Variants

Ashraf A. Basuni and William F. Carman

15 HBV Genotyping and Analysis for Unique Mutations

Anna Ayres, Stephen Locarnini, and Angeline Bartholomeusz

16 A One-Filter-Three-Probe Assay for Defective Interference (DI)

Effects of Naturally Occurring Core Internal Deletion (CID)

Variants of Human Hepatitis B Virus

Chiaho Shih and Ta-Tung Thomas Yuan.

17 Detection of Hypermodified Middle-Envelope (M) Proteins

Secreted from Naturally Occurring HBV Variants Containing

a preS2 Internal Deletion

Chiaho Shih and Pei-Ching Tai

18 Hepatitis B Viral Genotyping with the Research INNO-LiPA

HBV Genotyping Line Probe Assay

Sija De Gendt, Fred Shapiro, Jelena Juras, Els Van Assche,

Geert Maertens, and Erwin Sablon

\section{Part III. Molecular Biological Characterization}

19 Processing of Hepatitis B Virus Surface Proteins Volker Bruss

20 Binding of Duck Carboxypeptidase D to Duck Hepatitis B Virus

Stephan Urban

21 Nucleoprotein Transport of HBV Capsid Particles

Michael Kann

22 Phosphorylation Analysis of Hepatitis B Virus Core Protein

in Mammalian Cells

Jie Li, Yanyan Zheng, Jinah Choi, and Jing-hsiung $\mathrm{Ou}$

23 Study of HBV Replication Capacity in Relation to Sequence

Variation in the Precore and Core Promoter Regions

Fabien Zoulim, ShuPing Tong, and Christian Trépo 
24 A cis/trans Genetic Test for Pleiotropic Phenotypes

Associated with a Frequent Naturally Occurring Mutation at Amino Acid 97 of HBV Core Protein

Chiaho Shih and Ta-Tung Thomas Yuan...

25 Studying DHBV Polymerase by In Vitro Transcription and Translation

Jianming $\mathbf{H u}$

26 Expression and Purification of Functional Hepatitis B Virus Polymerase in the Baculovirus Insect Cell System

Lisa Lott, Lena Notvall, and Robert E. Lanford.

27 Localization of Duck Hepatitis B Virus Polymerase Within Cells Ermei Yao and John E. Tavis

28 Endogenous Polymerase Assay for the Analysis of Hepatitis B Virus in Transgenic Mice

Zhenming $\mathrm{Xu}$ and Jing-hsiung $\mathrm{Ou}$

29 Transcriptional Control of Hepatitis B Virus

Anneke K. Raney

30 In Vitro Reconstitution of $\varepsilon$-Dependent Duck Hepatitis B Virus Replication Initiation

Jürgen Beck and Michael Nassal

31 Hepatitis B Viruses: A Triple Threat for Malignant Transformation of Hepatocytes

Charles E. Rogler 


\section{Contributors}

KaRIM ABID • Division of Gastroenterology and Hepatology, University Hospital, Geneva, Switzerland

Anna Ayres • Victorian Infectious Diseases Reference Laboratory, North

Melbourne, Australia

Angeline Bartholomeusz • Victorian Infectious Diseases Reference Laboratory,

North Melbourne, Australia

Ashraf A. Basuni $\bullet$ West of Scotland Specialist Virology Centre, Gartnavel

General Hospital, Glasgow, Scotland, UK

JÜRGEN BECK • Department of Internal Medicine II / Molecular Biology, University

Hospital Freiburg, Freiburg, Germany

ScotT Bowden • Victorian Infectious Diseases Reference Laboratory, North

Melbourne, Australia

VolKer BRuss • Department of Virology, University of Goettingen, Göttingen, Germany

W. F. Carman - West of Scotland Specialist Virology Centre, Gartnavel General Hospital, Glasgow, Scotland, UK

J INAн CHOI $•$ Department of Molecular Microbiology and Immunology, Keck School of Medicine, University of Southern California, Los Angeles, CA

Hau Tim Chung • 5/25 Anderson St., Chatswood NSW 2067 Australia

Sija De Gendt $\bullet$ Hepatitis Diagnostics Program, Innogenetics N.V., Ghent, Belgium

J ANE W. S. FAnG - Research and Development, Ribapharm, Inc, Costa Mesa, CA

Mark A. Feitelson • Department of Pathology, Anatomy and Cell Biology, Thomas Jefferson University, Philadelphia, PA

Wolfram H. GerLICH • Institute of Medical Virology, Justus Liebig University, Giessen, Germany

DieTER GLEBE • Institute of Medical Virology, Justus Liebig University, Giessen, Germany

HANS JÖRg HACKer • Department of Virus Host Interactions, Deutsches

Krebsforschungszentrum, Heidelberg, Germany

JiAnMing Hu $•$ Department of Microbiology, Boston University School of Medicine, Boston, MA

KathY JACKSON $・$ Victorian Infectious Diseases Reference Laboratory, North Melbourne, Australia

Jelena Juras • Hepatitis Diagnostics Program, Innogenetics N.V., Ghent, Belgium Michael KanN • Institute of Medical Virology, Justus Liebig University, Giessen, Germany Michael M.C. LaI - Department of Molecular Microbiology and Immunology, Keck School of Medicine, University of Southern California, Los Angeles, CA VICKY C. H. LaI $\bullet$ Research and Development, Ribapharm, Inc, Costa Mesa, CA

ROBERT E. LANFORD $\bullet$ Department of Virology and Immunology, Southwest Foundation for Biomedical Research, San Antonio, TX 
Johnson Y. N. Lau • Former Chief Executive Officer, Ribapharm Inc., Costa Mesa, CA $\mathrm{J}_{\mathrm{IE}} \mathrm{LI} \cdot$ Department of Molecular Microbiology and Immunology, Keck School of Medicine, University of Southern California, Los Angeles, CA

Hsiang Ju LiN • Falls Church, VA

Margaret Littlejohn • Victorian Infectious Diseases Reference Laboratory, North Melbourne, Australia

JIE LiU • Department of Pathology, Anatomy and Cell Biology, Thomas Jefferson University, Philadelphia, PA

STEPHEN LocARnini • Victorian Infectious Diseases Reference Laboratory, North Melbourne, Australia

Lisa LotT • Department of Virology and Immunology, Southwest Foundation for Biomedical Research, San Antonio, TX

Geert Maertens • Hepatitis Diagnostics Program, Innogenetics N.V., Ghent, Belgium Thomas B. Macnaughton - Department of Molecular Microbiology and Immunology, Keck School of Medicine, University of Southern California, Los Angeles, CA

Maria Mildenberger • Department of Virus Host Interactions, Deutsches

Krebsforschungszentrum, Heidelberg, Germany

Michael NASSAL • Department of Internal Medicine II / Molecular Biology, University Hospital Freiburg, Freiburg, Germany

Francesco Negro • Division of Clinical Pathology, University Hospital, Geneva, Switzerland

Maria Grazi Niro • Department of Gastroenterology, Casa Sollievo della Sofferenza, San Giovanni Rotondo, FG, Italy

Lena Notvall • Department of Virology and Immunology, Southwest Foundation for Biomedical Research, San Antonio, TX

JING-HSIUNG Ou • Department of Molecular Microbiology and Immunology, Keck

School of Medicine, University of Southern California, Los Angeles, CA

Anneke K. RAney - Research and Development, Ribapharm, Inc, Costa Mesa, CA

MARIo RizZETTO • Department of Gastroenterology, University of Torino and

Azienda Ospedaliera S. Giovanni, Battista, Torino, Italy

Charles E. Rogler • Marion Bessin Liver Research Center, Department of Medicine, Albert Einstein College of Medicine, Bronx, NY

Erwin Sablon • Hepatitis Diagnostics Program, Innogenetics N.V., Ghent, Belgium

Claus H. SchröDER • Department of Virus Host Interactions, Deutsches

Krebsforschungszentrum, Heidelberg, Germany

Fred Shapiro • Department of Medical Affairs, Innogenetics N.V., Ghent, Belgium

Cнinно SнIн • Departments of Pathology, and Microbiology \& Immunology, WHO Collaborating Center for Tropical Diseases and Sealy Center for Vaccine Developments, University of Texas Medical Branch, Galveston, TX Antonina SMEdiLe - Department of Gastroenterology, University of Torino and Azienda Ospedaliera S. Giovanni, Battista, Torino, Italy

QIN Su • Department of Pathology, Tangdu Hospital, The Fourth Military Medical University, Xi'an, China 
Pei-Ching TaI • Center for Tropical Diseases, Department of Pathology, University of Texas Medical Branch, Galveston, TX

John E. TAvis • Department of Molecular Microbiology and Immunology, St. Louis University School of Medicine, St. Louis, MO

ShuPING Tong • The Liver Research Center, Rhode Island Hospital and Brown University School of Medicine, Providence, RI

Christian Trépo • INSERM U271, 151 Cours Albert Thomas, 69003, Lyon, France

STEPHAN URBAN • Department of Molecular Virology, University of Heidelberg, Heidelberg, Germany

Els Van Assche $\bullet$ Hepatitis Diagnostics Program, Innogenetics N.V., Ghent, Belgium

UlRIKE WEND • Institute of Medical Virology, Justus Liebig University, Giessen, Germany

ZheNMING Xu $\bullet$ Department of Molecular Microbiology and Immunology, Keck School of Medicine, University of Southern California, Los Angeles, CA

ERMEI Y University School of Medicine, St. Louis, MO

Ta-Tung Thomas Yuan $・$ Departments of Pathology, and Microbiology \& Immunology, WHO Collaborating Center for Tropical Diseases and Sealy Center for Vaccine Developments, University of Texas Medical Branch, Galveston, TX

Stefan Zeuzem - Professor of Medicine, Department of Internal Medicine II, University Hospital, Homburg/Saar, Germany

Wei Zhang • Department of Virus Host Interactions, Deutsches Krebsforschungszentrum, Heidelberg, Germany

YANYAN ZHENG $•$ Department of Molecular Microbiology and Immunology, University of Southern California, Keck School of Medicine, Los Angeles, CA

Fabien Zoulim • INSERM U271, 151 Cours Albert Thomas, 69003, Lyon, France 


\section{Contents for Volume 2}

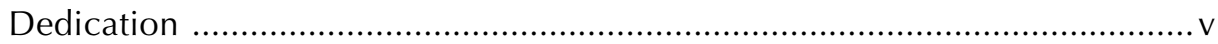

Foreword by Timothy M. Block and Baruch S. Blumberg ........................... vii

Foreword by T. Jake Liang .......................................................... ix

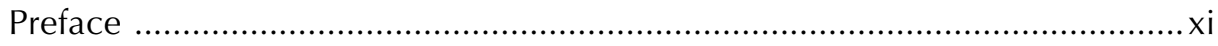

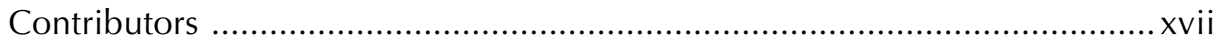

Contents for Volume 1 ...........................................................

Part I. Viral-Specific Immunological and Other Host Responses

1 Studying Host Immune Responses Against Duck

Hepatitis B Virus Infection

Darren S. Miller, Edward M. Bertram, Catherine A. Scougall, Ieva Kotlarski, and Allison R. Jilbert ........................................ 3

2 Measurement of Cell-Mediated Immune Response in Woodchucks

Stephan Menne and Paul J. Cote

3 Study of Liver-Specific Expression of Cytokines During

Woodchuck Hepatitis Virus Infection

Mengji Lu and Michael Roggendorf.

4 Induction of Anti-Hepatitis B Virus Immune Responses

Through DNA Immunization

Michael Geissler, Robert Weth, Christian F. Grimm,

Dörte Ortmann, and Hubert E. Blum

5 Monitoring Gene Expression Using DNA Microarrays During

Hepatitis B Virus Infection

Michael R. Beard and Stephen Locarnini

6 Determination of Hepatitis B Virus-Specific CD8 ${ }^{+}$T-Cell Activity in the Liver

Michelina Nascimbeni and Barbara Rehermann

7 Determining the Precursor Frequency of HBV Nucleocapsid

Antigen-Specific T Cells

Jennifer A. Waters and Howard C. Thomas

8 Detection and Characterization of Virus-Specific CD8 ${ }^{+}$

$\mathrm{T}$ Cells Using the Tetramer Approach

Xiao-Song He and Harry B. Greenberg

9 In Vitro Analysis of Hepatitis B Virus Specific CD4+ T Cells

Shilpa Chokshi and Nikolai V. Naoumov 
10 Induction of Humoral and Cellular Immune Responses to Hepatitis Delta Virus Through DNA Immunization in BALB/c Mice

Ren-Shiang Lee, Shih-Jer Hsu, Li-Rung Huang, Hui-Lin Wu, Shiou-Lin Lin, Ding-Shinn Chen, and Pei-Jer Chen

\section{Part II. In Vitro and In Vivo Models}

11 Infection of Primary Chimpanzee Hepatocytes with Recombinant Hepatitis D Virus Particles:

A Surrogate Model for Hepatitis B Virus

Azeneth Barrera and Robert E. Lanford

12 Study of the Endocytosis and Intracellular Localization of Subviral Particles of Hepatitis B Virus in Primary Hepatocytes

Dieter Glebe and Wolfram $\mathbf{H}$. Gerlich

13 The Tupaia Model for the Study of Hepatitis B Virus:

Direct Infection and HBV Genome Transduction of Primary Tupaia Hepatocytes

Fritz von Weizsäcker, Josef Köck, Sabine MacNelly, Shaotang Ren, Hubert E. Blum, and Michael Nassal

14 Delivery of Hepatitis B Virus Therapeutic Agents Using Asialoglycoprotein Receptor-Based Liver-Specific Targeting Masayoshi Konishi, Catherine $\boldsymbol{H}$. Wu, and George $\mathbf{Y}$. Wu 163

15 Woodchuck Hepatitis Virus Hepatocyte Culture Models

Norma D. Churchill and Tomasz I. Michalak.

16 Duck Hepatitis B Virus Primary Hepatocyte Culture Model Olivier Hantz and Fabien Zoulim 189

17 Enhancement of Infection of HepG2 Cells in Culture by Predigestion of Hepadnavirus with V8 Protease

Xuanyong Lu and Timothy M. Block

18 Construction of Recombinant Adenoviruses that Produce Infectious Hepatitis B Virus

Martin Sprinzl, Jérôme Dumortier, and Ulrike Protzer

19 Baculovirus-Mediated Gene Transfer for the Study of Hepatitis B Virus

Harriet C. Isom, Ayman M. Abdelhamed, John P. Bilello, and Thomas G. Miller

20 Transgenic Hepatitis B Virus Mouse Model in the Study of Chemotherapy

John D. Morrey 
21 Transplantation of Human Hepatocytes in Immunodeficient

UPA Mice: A Model for the Study of Hepatitis B Virus

Jörg Petersen, Martin R. Burda, Maura Dandri, and Charles E. Rogler

22 Duck Hepatitis B Virus Model in the Study of Hepatitis B Virus

Lucyna Cova and Fabien Zoulim

23 Hepatitis B Virus Transgenic Severe Combined Immunodeficient Mouse Model of Acute and Chronic Liver Disease

Mark A. Feitelson, Jonathan D. Larkin, and Raymond F. Schinazi... 269

24 The Chimpanzee Model: Contributions and Considerations for Studies of Hepatitis B Virus

Pascal Gagneux and Elaine A. Muchmore

25 Hepatitis B in Liver Transplant Recipients as a Special Model of Antiviral Drug Development

Robert G. Gish and Adil Wakil

26 Hepatitis Delta Virus Transfection for the Mouse In Vivo Model

Jinhong Chang, Anthony Lerro, and John M. Taylor

27 Hepatitis Delta Virus RNA Transfection for the Cell Culture Model

Thomas B. Macnaughton and Michael M. C. Lai...

\section{Part III. Antiviral Testing and Clinical Studies}

28 Analysis of Hepatitis B Virus Dynamics and Its Impact on Antiviral Development

Manuel Tsiang and Craig S. Gibbs 361

29 Genotyping Anti-Hepatitis B Virus Drug Resistance

Eric J. Bourne, Josée Gauthier, Vincent A. Lopez, and Lynn D. Condreay

30 A Parsimonious Method for Screening Drug Combinations for Antihepadnaviral Activity Using a Parametric Dose-Response Surface Approach

Tim Shaw and Stephen Locarnini

31 Hepatitis B Virus: Where Are We and Where Are We Going?

Michael P. Manns, Johannes Hadem, and Heiner Wedemeyer

32 Designing Studies to Evaluate Anti-Hepatitis B Virus Therapies:

From the Perspective of Studies for the Registration of Pharmaceutical Products

Alison B. Murray 
33 Specific Considerations in the Design of Hepatitis B Virus

Clinical Studies in the Far East

Man-Fung Yuen and Ching-Lung Lai.

457

34 Studying the Treatment of Chronic Hepatitis B Viral Infection in Special Populations

Robert G. Gish and Stephen Locarnini .

465

35 Designing Clinical Development Programs for Anti-Hepatitis B Virus Drugs

Nathaniel A. Brown

36 Testing Antivirals Against Hepatitis Delta Virus:

Farnesyl Transferase Inhibitors

Bruno B. Bordier and Jeffrey S. Glenn

Index 